\title{
The impact of OFDI reverse technology spillover on China's technological progress: Analysis of provincial panel data
}

\author{
Li Shuyan \\ Zhejiang University of Technology, Hangzhou, \\ Ningbo University of Finance and Economics \\ P. R. China \\ 365412788@qq.com
}

\author{
Michal Fabus \\ Department of economics and finance, School of Economics and \\ Management in Public Administration in Bratislava \\ Slovakia \\ michal.fabus@vsemvs.sk
}

\begin{abstract}
In recent years, China's foreign direct investment (OFDI) has grown rapidly. While promoting economic development of a host country, it also has a certain impact on technological progress of a home country through the reverse technology spillover effect. However, the source of China's OFDI is not unevenly distributed, and OFDI of the Eastern coastal economically developed provinces and cities has the highest proportion. At the same time, due to large differences in economic development levels and technical levels of various provinces and cities, the absorption effect of OFDI reverse technology spillovers must be different. This paper takes the patent grant amount as a technical indicator and uses panel data on various provinces and cities in China to empirically test the reverse spillover effect of OFDI on China's technological progress and regional differences in it. Overall, there is a long-term stable equilibrium relationship observed between China's OFDI and domestic technological progress, but the correlation coefficient is not high. In terms of regions, the largest value is observed on the East, the second largest - on the West, and the smallest - in the Central region. The proportion of China's OFDI participating in foreign production and technology research and development is still relatively low, so the coefficient of influence on technological progress is not high. The government should actively guide and promote Chinese enterprises to increase foreign investment in production, research and development, and thus increase the contribution of OFDI to technological progress.
\end{abstract}

Keywords: OFDI, reverse technology spillover, regional differences.

JEL Classification: F21, F22 


\section{INTRODUCTION}

OFDI (Outward Foreign Direct Investment) is a kind of cross-border economic activity in which home country investors invest in various production factors and acquire management rights through new establishments or mergers and acquisitions. Cross-border economic activities often lead to cross-border technological spillovers. Geographical distance is related to the cost of transportation and communication efficiency between a parent company and a subsidiary company (Stopford, 2008). It is customary to refer to the technology spillover of FDI to a host country as a positive technology spillover. The technology spillover of FDI to a home country is called reverse technology spillover. Since the 1980s, OFDI of developing countries flowing to developed countries has become more and more common, thus raising concerns about technology resourcing OFDI in developing countries. In the 1990s, scholars began systematically studying the reverse technology spillover of OFDI which gradually became one of the hot topics in the field of crossborder investment.

Current Chinese trade policy is based on strengthening the coordination with foreign political and economic interests (Raišienè et al., 2019). China officially proposed the "going out" strategy in the early 21st century, which greatly promoted the development of OFDI in Chinese enterprises. In 2016, China conducted non-financial direct investments in 7961 overseas enterprises in 164 countries and regions, with the accumulated investment of 170 billion US dollars, a year-on-year increase of $44 \%$, thus ranking first in developing countries for many years. Among these investments, a considerable part is the technologyseeking OFDI flowing to developed countries. The realization of domestic technological progress through the reverse technology spillover effect of OFDI is of great significance to China's economic development.

In the following sections, after reviewing literature on the related basic issues, we will analyze in detail the growth of china's OFDI and the differences in OFDI sources. subsequently, we offer an econometric model, using panel data from various provinces and cities to empirically analyze regional differences in China's OFDI reverse spillover effects. finally, policy recommendations are proposed in combination with the test results.

\section{LITERATURE REVIEW}

In this section, we will briefly review the development of FDI theory, focusing on the reverse effect of developing countries' direct investment in OFDI reverse technology. Summarize the relevant research progress and conclusions about OFDI reverse technology spillovers at home and abroad.

Kogut and Chang (1991) first studied the reverse technology spillover effect of OFDI. Based on the data of Japan's industry level, they establish an econometric model for empirical analysis. The results show that Japan's OFDI in the United States has a significant role in promoting the technological advancement of Japanese domestic enterprises - that is, the reverse technology spillover effect. Serapio and Dalton (1999) conducted an empirical analysis of FDI in the United States and concluded that foreign companies can improve their innovation by establishing R\&D institutions in the United States or by directly acquiring local $R \& D$ institutions and R\&D resources in the United States. ability. However, not all countries' OFDI have reversed technology spillovers, and some studies have reached the opposite conclusion: For example, Bitzer and Kerekes (2008) used data from 10 manufacturing industries in 17 OECD countries from 1973 to 2000. The conclusion is that the OFDI outflow stock has a negative correlation with the total factor productivity of the home country manufacturing industry (Fosfuri, Motta, 1999). Monopolistically competitive firms try to maximize profit or minimize losses by producing quantity of production where marginal revenues equal marginal costs. Economic profit in the industry is an attractive motive for other firms outside the industry to get involved in the same industry and motivating them to enter. (Pokrivcak, et.al, 2019). Investment 
development cycle theory (Dunning, 1977), technical innovation and industry upgrading theory (Buckley, P.J.; Casson, M.A., 1981) etc.

With the rapid growth of China's OFDI in the world, the focus on China's OFDI is increasing. Lee, M., Yin, X., Lee, S., Weng, D. H., \& Peng, M. (2015) explained the mechanism of OFDI reverse spillover based on the components of the innovation network. Yuan, X. and Zhang, Y. (2018) empirical analysis using the L-P model shows that China's outward FDI, especially for countries with rich R\&D factors, has a significant effect on domestic total factor productivity. However, many scholars have drawn conclusions: Wang, Y. and Liu, S. (2008) empirical analysis using the international R\&D spillover regression framework shows that the international R\&D spillover with OFDI as the transmission mechanism has not played a role in China's technological progress. enhancement. The study by Zhao, W., He, Y. (2006)) also shows that the role of foreign direct investment in China's technological progress is not very obvious. In the developing world, especially young people are facing the challenge of globalization (Vdovtsova, 2008; Nechtelberger, 2017; Morreale et al., 2018).

With the development of practice and the deepening of research, many scholars have explored the motivations and methods of FDI from the perspective of developing countries and have produced many FDI theoretical results. These theories include Theory of Small-Scale Technology (Wells, 1977). From the perspective of market seeking motivation, the market size is undoubtedly an important factor affecting the choice of OFDI location. The larger the size of the host country market, the greater the potential for FDI to achieve economies of scale in local investment operations, and therefore proportional to the inflow of FDI (Bevan, Estrin \& Meyer, 2004). FDI are a global phenomenon whose share in international business is steadily rising and generates large capital injections. FDI has been and continues to be an important factor in the development of transition countries. They help create new jobs, which can lead to an influx of new technologies, and in total they provide the necessary capital to restore a successful transition to the market economy (Fabus, 2015, 2017, 2018; Shuyan, 2019).

The above literature indicates that the current research results on the spillover effect of OFDI reverse technology are rich, but the conclusions on the existence of the reverse technology spillover of OFDI in China are not consistent, or even the opposite conclusion. In addition, many scholars have tried to interpret the location choice of China's OFDI from the perspective of the host country system, and further enrich the connotation of China's OFDI location selection theory (Deng Ming, 2012; Jia Yucheng, 2017). The main reasons are two aspects: First, there are deviations in the calculation of China's technological progress indicators, and total factor productivity (TFP) is used as an index. The calculation methods and parameters are very different, so the conclusions are different. Second, the difference in OFDI regions in China large, general analysis ignores the corresponding differences in OFDI technology spillovers in different regions. This paper will use the panel data of OFDI in various provinces of China to compare the objective patent authorization quantity as the technical progress index, and empirically test the difference of OFDI reverse technology spillover in different regions of China.

\section{METHODOLOGY}

\subsection{Model construction}

The earliest construction technique spillover effect measurement model was Coe and Helpman (1995), who used the international R\&D spillover regression method to verify the technical spillover effects of the import channel. The expression is as follows:

$$
\ln T_{i t}=\alpha_{i}+\alpha_{i t}^{d} \ln S_{i t}^{d}+\alpha_{i t}^{f} \ln S_{i t}^{f}+\varepsilon_{i t}
$$


i represents different countries and regions, $t$ represents time; Tit represents the technical level of country i in period t; $S_{i t}^{d}$ represents the domestic R\&D capital stock in period t; $S_{i t}^{f}$ represents the foreign $\mathrm{R} \& \mathrm{D}$ capital stock obtained for international trade in period t. ${ }^{\alpha_{i t}^{d}}$ For the t-time i country's internal R\&D capital stock to the technical level $T_{\text {it }}$ of flexibility; $\alpha_{i t}^{f}$ for the t period i country's foreign R\&D capital stock to the technical level $T_{\text {it }}$ of flexibility. ${ }^{\alpha_{i}}$ is a constant term and ${ }^{\text {it }}$ is a random error term.

The model reflects that a country's technological advancement depends not only on domestic R\&D investment, but also on the spillover of foreign R\&D capital stocks. Based on the above model, this paper mainly considers the impact of domestic $\mathrm{R} \& \mathrm{D}$ capital stock and foreign $\mathrm{R} \& \mathrm{D}$ capital stock on the technological progress. Build the following model:

$$
\ln T_{i t}=\alpha_{i}+\alpha_{i t}^{d} \ln S_{i t}^{d}+\alpha_{i t}^{o f d i} \ln S_{i t}^{o f d i}+\varepsilon_{i t}
$$

It shows the technical level $T_{\text {it }}$ of i province in t period, $S_{i t}^{d}$ indicates the domestic R\&D capital stock of i province in t period, ${ }_{i t}^{\text {ofdi }}$ indicates the overseas R\&D capital stock caused by foreign direct investment in period i. $\alpha_{i t}^{d}$ is the elasticity of the domestic R\&D capital stock of the province of t period to the technical level $T_{\text {it }} ; \alpha_{i t}^{\text {ofdi }}$ the elasticity of the foreign R\&D capital stock of the t-country country to the technical level $T_{\text {it }} \alpha_{i}$ is a constant term and $\varepsilon_{\text {it }}$ is a random error term.

\subsection{Data source}

In the case of comprehensive consideration of the connotation of the indicators and the availability of the data, the selection and calculation of the variables are as follows:

Domestic technical level $T_{\text {it }}$ : Selecting the number of patent grants in various provinces and cities in China as a technical progress indicator is relatively more objective and the data source is relatively straightforward. The data in this paper comes from the "China Science and Technology Statistical Yearbook".

Domestic R\&D capital stock $S_{i t}^{d}$ : Calculated by the perpetual deposit method, the main used data is the annual $R \& D$ expenditure internal expenditure and depreciation rate $\delta$. The above data can be found in the "China Statistical Yearbook" and "China Science and Technology Statistical Yearbook".

OFDI-induced overseas R\&D capital stock $S_{i t}^{\text {ofdi }}$ : The calculation method proposed by LP (2001) is used to obtain the overseas R\&D capital stock obtained by China's direct investment in the host country. The main data used are foreign R\&D inputs, OFDI data from China and provinces. The above data can be found in the "Statistical Bulletin of China's Foreign Direct Investment" jointly issued by the Ministry of Commerce, the National Bureau of Statistics and the State Administration of Foreign Exchange.

This paper selects the data from 2003-2016 as the research interval, and selects 31 provinces and municipalities except Hong Kong, Macao and Taiwan as the research object. The overall data is the panel of 31 provinces and cities for 14 years. The reason why it was chosen after 2003 is that, after 2003, China's "going out" strategy has entered an in-depth implementation stage, and the scale of foreign investment has 
gradually expanded. On the other hand, the foreign investment data of various provinces and cities in China have only been compared in 2003. Detailed statistics.

\section{EMPIRICAL RESULTS AND DISCUSSION}

\subsection{Development and regional characteristics of OFDI in China}

At the beginning of China's reform and opening up, many companies in China have gone abroad to invest abroad. However, in the 1980s and 1990s, China's OFDI was still at a relatively low level relative to the scale of attracting foreign investment in China. Since 2002, China's OFDI has embarked on a fastgrowing "fast lane". The total OFDI total has increased from 2.7 billion U.S. dollars in 2002 to an all-time high of 196.2 billion U.S. dollars in 2016. Climb to the second place in the world (as shown in Figure 1).

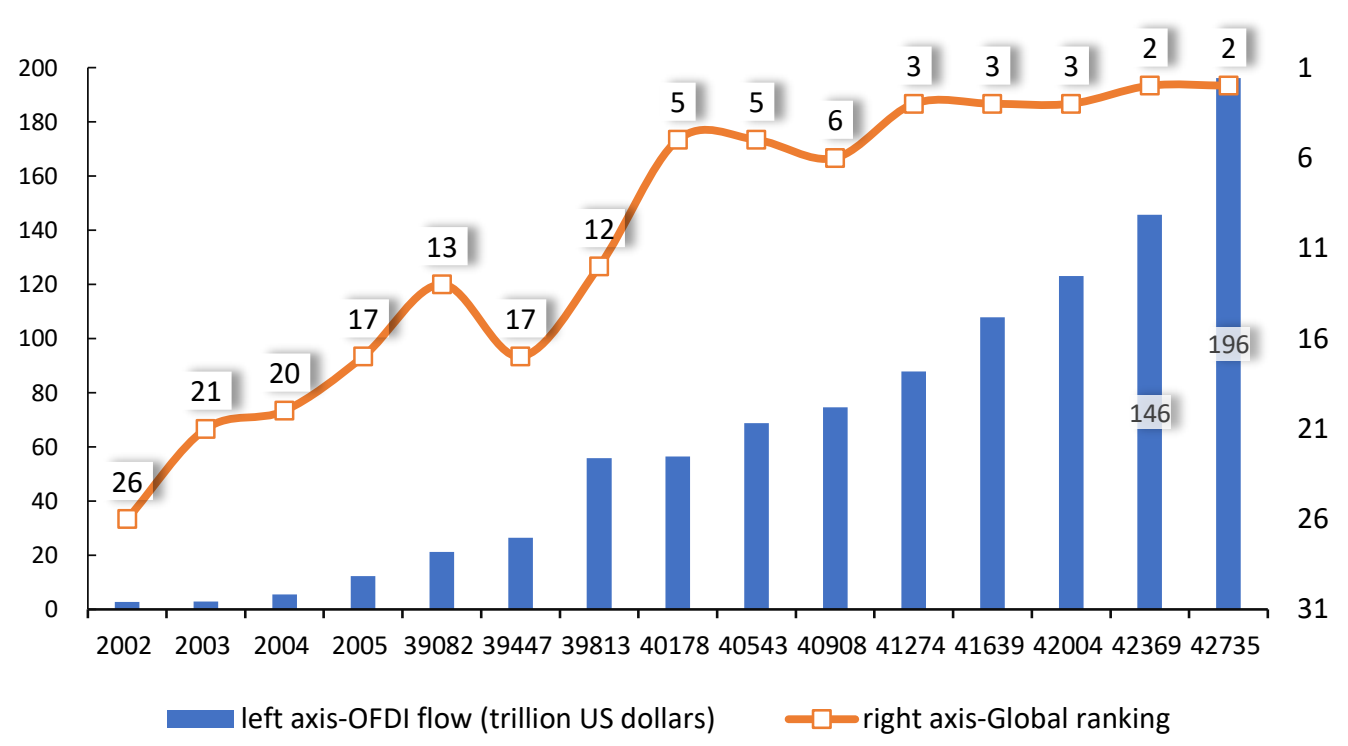

Figure 1. China's OFDI flow value and global ranking changes

Source: Authors' results. China's foreign direct investment Yearbook (2002-2016)

As far as China's foreign direct investment sources are concerned, China's foreign direct investment enterprises have obvious regional imbalances. Due to historical and geographical factors, most of China's foreign direct investment is distributed in the eastern coastal areas, showing the pattern of foreign direct investment of local enterprises with "eastern and weak west".

From the OFDI traffic data (Figure 2), in 2003, the OFDI in the eastern region reached 680 million US dollars, accounting for $89 \%$ of the local government's OFDI traffic in that year, far exceeding the size of the central and western regions. However, from 2003 to 2008, the pattern of OFDI in the east, west and west of China changed significantly: the proportion of OFDI traffic in the eastern region continued to decline and fell to $66 \%$ in 2008; the scale of OFDI in the central and western regions increased rapidly, reaching 840 million US dollars, the proportion increased. Up to 34\%. However, this situation has reversed since 2009. Since 2009, the growth rate of OFDI in the eastern region has re-started ahead of the central and western regions, and its proportion has been rising. By 2016, the OFDI traffic in the eastern region reached US $\$ 127.46$ billion, accounting for $85 \%$ of the national total. The proportion of the central and 
western regions continued to decline. By 2016, the total OFDI flow was US\$22.97 billion, accounting for only $15 \%$ of the national total.

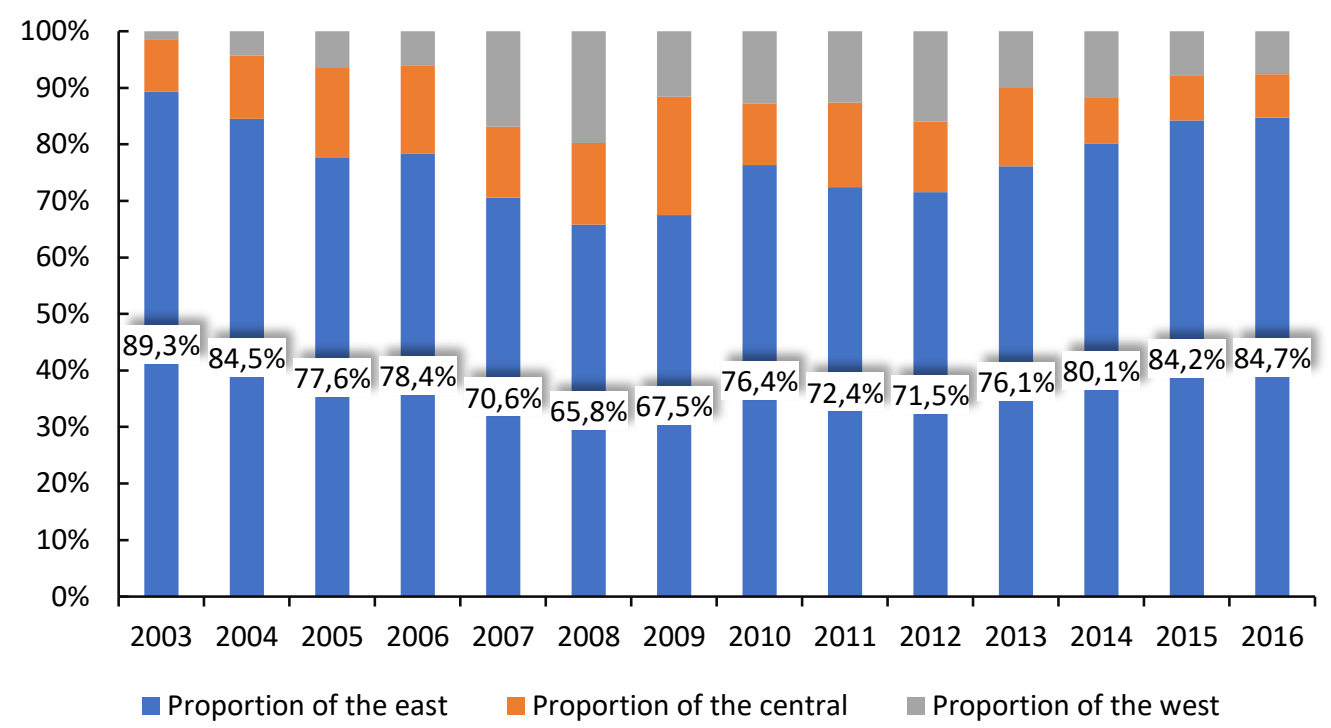

Figure 2. Proportion of Eastern, Central and Western Provinces

Source: Authors' results. China's foreign direct investment Yearbook (2002-2016)

According to the province's ranking, in 2016, Shanghai, Guangdong, Tianjin, Beijing, Shandong, Zhejiang, Jiangsu, Henan, Fujian, and Hebei ranked among the top 10 local foreign investment flows, and the investment flow reached 129.24 billion US dollars, which accounted for the direct foreign investment of local enterprises in China. $85.9 \%$ of the total investment. Shanghai ranked first, with a total investment of 24 billion US dollars, $16 \%$ of local enterprises' OFDI traffic in the same year; followed by Guangdong Province, accounting for 15.6\%; Tianjin ranked third, accounting for $11.9 \%$. Proportion of Eastern, Central and Western Provinces.

\subsection{Measurement of domestic $R \& D$ capital stock}

For the domestic R\&D capital stock, the perpetual inventory method is used to calculate the R\&D capital stock of each province and city. The calculation formula is as follows:

$$
S_{i t}^{d}=R D_{i t}+(1-\delta) S_{i(t-1)}^{d}
$$

$S_{i t}^{d}$ represents the R\&D capital stock of the i province of t period; $\delta$ is the depreciation rate of the $\mathrm{R} \& \mathrm{D}$ capital stock, which is $5 \%$ with reference to the usual practice. $R D_{i t}$ is the actual R\&D expenditure of $i$ provinces and cities in the $t$ period calculated at the constant price in 2003. The nominal R\&D expenditure data of various provinces and cities over the years comes from the China Science and Technology Statistical Yearbook. The calculation formula of $R D_{i t}$ is as follows:

$$
S_{i 0}^{d}=R D_{i 0} /\left(g_{i}+\delta\right)
$$


$\mathrm{g}_{i}$ is the actual annual growth rate of R\&D expenditure for i province in the five years from 2003 to 2008. $\mathrm{t}=0$ represents the relevant data for the base period in 2003 .

The calculation results show that the top six R\&D capital stocks in China are all in the eastern coastal provinces and cities, and Guangdong ranks first in the country. In 2016, the total R\&D capital reached US\$673.6 billion, and Jiangsu and Beijing were separated by two or three, respectively, reaching RMB 649.6 billion. 621.1 billion yuan. This is followed by Shandong (502.4 billion yuan), Zhejiang (388.7 billion yuan) and Shanghai (386.9 billion yuan). The central provinces only Hubei (193.1 billion yuan) entered the top 10, ranking seventh; while the west only Sichuan (187.2 billion yuan) entered the top ten, ranking eighth.

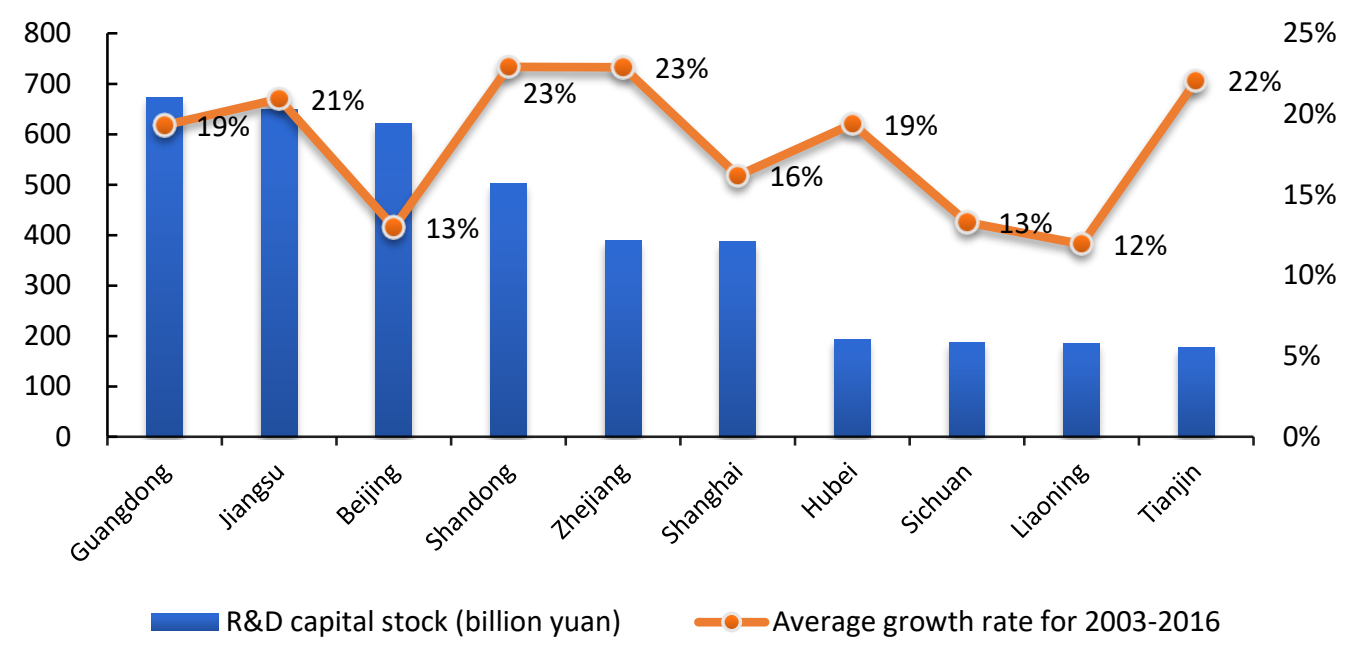

Figure 3. Proportion of Eastern, Central and Western Provinces

Source: Authors' results. According to the calculation result of formula (3) and formula (4))

\subsection{Estimation of overseas $R \& D$ capital stock}

Through OFDI, China can obtain the overflow of R\&D capital stock in the host country. There is no direct statistics on foreign R\&D capital stock data. Most of the data on this variable at home and abroad use the calculation method proposed by LP (2001) to obtain the overseas R\&D capital stock obtained by the mother country. The formula is as follows:

$$
S_{t}^{o f d i}=\sum\left(O F D I_{j t} / Y_{j t}\right) S_{j t}
$$

In formula (5), $O F D I_{j t}$ is the stock of investment in the target country $\mathrm{J}$ in China during the $\mathrm{t}$ period, $Y_{j t}$ is the GDP of the host country $\mathrm{j}$ in the $\mathrm{t}$ period, and $S_{j t}$ represents the R\&D capital stock of the J country in the $\mathrm{t}$ period.

According to formula (5), we can calculate the R\&D capital stock caused by China's global OFDI. The GDP data of each country comes from the World Bank WDI database; R\&D expenditure comes from the World Bank, UNESCO and OECD statistics; China's foreign direct investment stock data from countries are derived from the China Foreign Investment Statistics Bulletin. According to the situation of China's OFDI, we select destinations with more foreign direct investment (remove Hong Kong, Cayman Islands and British Virgin Islands, etc.), and then compare the continuity and completeness of the data, select the United States, Singapore, the United Kingdom, the Netherlands, Russia. 12 countries including Canada, France, Germany, South Korea, Sweden, Japan and Brazil were selected as samples. The calculation method of the R\&D capital stock in the sample country is similar to the domestic R\&D capital stock, and is also 
estimated by the perpetual inventory method. The formula for calculating the R\&D capital stock of country $\mathrm{j}$ in $\mathrm{t}$ period is as follows:

$$
S_{j t}=R D_{j t}+(1-\delta) S_{j(t-1)}
$$

In formula $(6), \delta_{\text {is }}$ the depreciation rate of $\mathrm{R} \& \mathrm{D}$ capital stock, which is $5 \%$ with reference to the international practice. In the process of calculation, the calculation of the variables $R D_{j t}$ to be used can be obtained by multiplying the GDP of each country by the R\&D expenditure of each country as a percentage of GDP.

In the decade of 2007-2016, China's OFDI traffic to the EU increased by 8.5 times. By the end of 2016, China's stock of OFDI to the EU reached US\$68.94 billion, accounting for 36.5\% of China's OFDI stock in developed economies, surpassing China's OFDI stock in the US (US\$60.56 billion, 31.7\%), in China's OFDI in developed economies. Ranked first (Table 2). Under the Sino-US trade dispute and the increasingly severe restrictions on US investment in China, it is a general trend for China's OFDI to accelerate its transition from North America to Europe.

Then, according to the proportion of the OFDI stocks in each province and the whole country, the stock of R\&D capital in overseas provinces and municipalities is calculated. Calculated as follows:

$$
S_{i t}^{o f d i}=\left(O F D I_{i t} / O F D I_{t}\right) S_{t}^{o f d i}
$$

In formula (6), ${ }^{O F D I_{j t}}$ represents the stock of OFDI in the period of i province; ${ }^{O F D I_{t}}$ represents the total stock of OFDI during the period $t ;{ }_{t}^{\text {ofdi }}$ represents the stock of R\&D capital of OFDI in China during the t period.

Through calculation, the R\&D capital stock of OFDI in each province is obtained. According to the results, China's 2016 OFDI overseas R\&D capital stock reached US $\$ 420$ billion. As of 2016, there are 8 provinces and cities with over 7 billion overseas R\&D stocks, namely Guangdong, Shanghai, Beijing, Shandong, Jiangsu, Zhejiang, Tianjin and Liaoning.

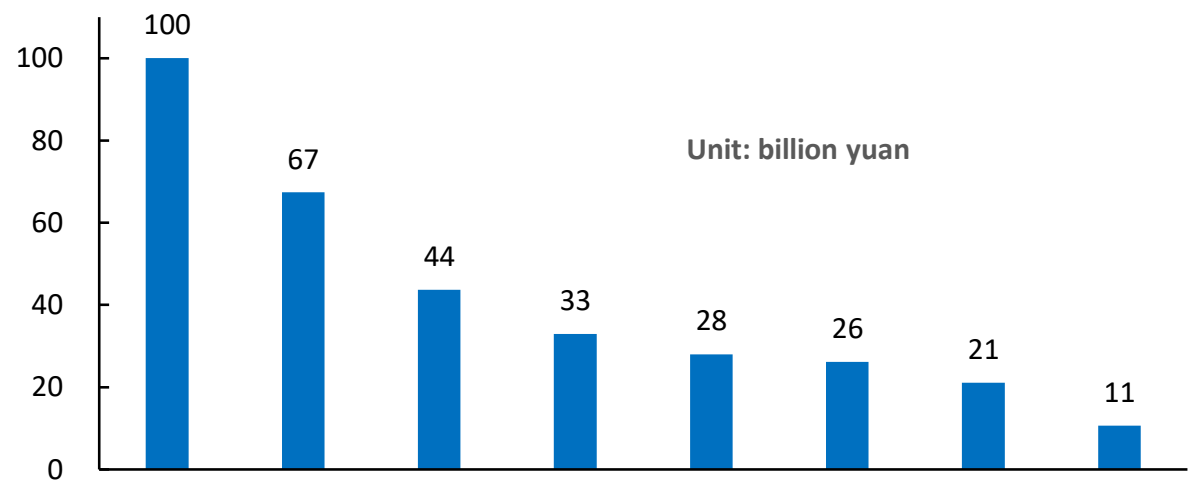

Figure 4. Top Ten Provinces of 2016 OFDI Overseas R\&D Capital Stock (Unit: US\$100 million)

Source: Authors' results. According to the calculation results of formula (6) and formula (7)

\subsection{Empirical test and results}

We select the panel data of 31 provinces, municipalities and autonomous regions in China from 2003 to 2016 and conducts panel data regression analysis on the impact of OFDI and domestic R\&D stocks on the technological progress of 31 provinces and autonomous regions in China. The required variables have 
been calculated in the previous section. In order to avoid the occurrence of pseudo-regression, it is first necessary to test the stability of each variable to see if the economic variables have a time trend. The ADF unit root test method is used to test the stability of the variables and determine whether to adopt Cointegration analysis. The test results show that the ADF values of the original sequence are less than the critical value, that is, all variables are stationary variables, and we can do long-term cointegration analysis.

Table 1

Results of Unit Root Test (ADF)

\begin{tabular}{|c|c|c|c|c|c|}
\hline Variable & Difference & $\begin{array}{l}\text { Test Type } \\
(\mathrm{C}, \mathrm{T}, \mathrm{L})\end{array}$ & t statistic & $\mathrm{P}$ value & Conclusion \\
\hline \multirow{2}{*}{ LNT } & 0 & $(\mathrm{C}, \mathrm{T}, 0)$ & $-3.490559 * * *$ & 0.0087 & unstable \\
\hline & 1 & $(\mathrm{C}, \mathrm{T}, 0)$ & $-5.450456^{* *}$ & 0.0000 & stable \\
\hline \multirow{2}{*}{$\ln S^{d}$} & 0 & $(\mathrm{C}, \mathrm{T}, 0)$ & $--3.766701 * * *$ & -0.0035 & unstable \\
\hline & 1 & $(\mathrm{C}, \mathrm{T}, 0)$ & $-5.470254 * * *$ & 0.0000 & stable \\
\hline \multirow[b]{2}{*}{$\operatorname{lnSofdi}$} & 0 & $(\mathrm{C}, 0,0)$ & $-4.183033^{* * *}$ & 0.0008 & stable \\
\hline & 1 & (C, 0,0 & $-5.286838 * * *$ & 0.0000 & stable \\
\hline
\end{tabular}

Source: The data in this table is calculated by eviews6.0 software. The test types C, T, and L respectively indicate that the unit root test equation includes a constant term, a time trend term, and a lag order, and 0 indicates that the time trend term or the lag order is not included. ${ }^{* *},{ }^{* *}$, and * after the t value indicate significant values at the $1 \%, 5 \%$, and $10 \%$ significance levels, respectively.

First of all, the overall inspection of China, and then divided into three groups of eastern, central and western areas for testing. According to the general classification, the eastern region includes 11 provinces (cities) including Beijing, Tianjin, Hebei, Liaoning, Shanghai, Jiangsu, Zhejiang, Fujian, Shandong, Guangdong, and Hainan; the central part includes Shanxi, Jilin, Heilongjiang, Anhui, Jiangxi, and Henan. There are 8 provinces including Hubei, Hunan and the west; 11 provinces (municipalities and autonomous regions) including Inner Mongolia, Guangxi, Chongqing, Sichuan, Guizhou, Yunnan, Shaanxi, Gansu, Qinghai, Ningxia and Xinjiang. However, in the process of data processing, the eastern regions eliminated the three provinces of Hebei, Liaoning and Hainan, which are obviously inconsistent with the data characteristics of other eastern provinces; the western region eliminated the smallest OFDI in Tibet, Qinghai and Ningxia, and Chongqing with significantly higher OFDI; The east remains unchanged. This treatment not only ensures that the data characteristics of each region is almost always, but also includes 8 provinces in each region, which is more convenient for data analysis.

The test results show that the variables $\mathrm{LnT}, \ln S \mathrm{~d}$ and $\ln S$ ofdi have a cointegration relationship at a critical value of $5 \%$. The overall estimation results of China are as follows:

$$
\begin{aligned}
\operatorname{LnT}= & 3.873726+0.81743 \operatorname{Ln} \mathrm{S}^{\mathrm{d}}+0.183320 \operatorname{Ln} S^{\text {ofdi }} \\
& \left(28.94386^{* * *}\right) \quad\left(30.37254^{* * *}\right) \quad\left(9.216230^{* * *}\right)
\end{aligned}
$$

$\mathrm{R} 2=0.9598167$, after adjustment $\mathrm{R} 2=0.947828, \mathrm{DW}=0.319929, \mathrm{~F}$ value $=92.65968$. The values in parentheses are the statistical values of the coefficients; ${ }^{* * * *}, * *$, and $*$ indicate significant at the $1 \%, 5 \%$, and $10 \%$ levels, respectively.

Estimated results for the eastern region: 


$$
\begin{gathered}
\operatorname{Ln} T_{=4.231833+0.654698} \operatorname{Ln} \mathrm{S}^{\mathrm{d}}+0.28845^{2 n} S^{\text {ofdi }} \\
\left(7.542515^{* * *}\right) \quad\left(5.415862^{* * *}\right) \quad\left(3.77336^{* * *}\right)
\end{gathered}
$$

$\mathrm{R} 2=0.768043$, after adjustment $\mathrm{R} 2=0.763787, \mathrm{DW}=0.109951, \mathrm{~F}$ value $=180.4577$.

Estimated results for the Central Region:

$$
\begin{gathered}
L n T=2.837809+0.980228 \operatorname{LnS}^{\mathrm{d}}+0.087866 \operatorname{LnS}^{\text {ofdi }} \\
\quad\left(2.747393^{* * *}\right) \quad\left(5.339748^{* * *}\right) \quad\left(1.787015^{*}\right)
\end{gathered}
$$

$\mathrm{R} 2=0.9598167$, after adjustment $\mathrm{R} 2=0.947828, \quad \mathrm{DW}=0.319929, \mathrm{~F}$ value $=92.65968$.

Estimated results for the western region:

$$
\begin{aligned}
& L n T=3.961265+0.738262 L n \mathrm{~S}^{\mathrm{d}}+0.166386 \operatorname{Ln} S^{\text {ofdi }} \\
& \begin{array}{l}
(15.92279 * * *) \quad\left(13.22768^{* * *}\right) \quad(4.546964 * * *)
\end{array}
\end{aligned}
$$

$\mathrm{R} 2=0.787335$, after adjustment $\mathrm{R} 2=0.783433, \quad \mathrm{DW}=0.131039, \mathrm{~F}$ value $=201.7715$.

The results show that the coefficient estimates of all explanatory variables are positive, and both are significant at the $1 \%$ significance level, indicating that the domestic R\&D expenditure and the foreign R\&D capital stock of the OFDI channel overflow have the number of domestic patent grants. Significant positive impact, so domestic R\&D investment and OFDI's reverse technology spillover effects all contribute to improving China's domestic innovation capability.

From the perspective of the estimated value of the coefficient, in general, the impact of the OFDI reverse technology spillover effect on domestic technological progress is relatively small compared with the domestic R\&D expenditure. According to national data, for every 1\% increase in domestic R\&D capital, the number of patent grants in China increased by $0.82 \%$; and for every $1 \%$ increase in foreign R\&D capital brought by OFDI, the number of patent grants in China increased by only $0.18 \%$. The domestic East, Central and West sub-regions are also basically the same.

From the effect of OFDI reverse technology spillover, the largest in the east, the OFDI-induced foreign R\&D capital stock Sd increases by 1\%, the number of domestic patent grants will increase by $0.29 \%$; the west is second, the Midwest is close, and the foreign R\&D capital stock Sd caused by OFDI For every $1 \%$ increase, the number of domestic patent grants will increase by $0.17 \%$; the smallest in the central region, and the increase in foreign R\&D capital stock Sd caused by OFDI will increase by $0.88 \%$.

\section{CONCLUSIONS}

Based on the panel data of China's provinces and cities, this paper examines the reverse technology spillover effects of OFDI in different regions of China. Although China's OFDI reverse technology spillover effect exists, the correlation coefficient is not high. There are also large differences in different regions. In combination with the reality of China's OFDI, several policy recommendations were proposed.

First of all, despite the rapid expansion of China's OFDI, the degree of internationalization of Chinese companies is still not high, and it has not been fully embedded in the industrial chain of developed countries and has not obtained a large technological spillover. In key technology areas, Chinese companies are still at the low end of the industrial chain, and there is still a big gap between technological innovation capabilities and developed countries. Acquiring technology through OFDI is a long process, and Chinese companies need to continue to accumulate experience to gradually climb to the high end of the industry chain.

Secondly, the total amount of OFDI in the central and western regions of China is relatively small, and the weak connection with the world market is not enough to produce a large reverse technology spillover effect. At the same time, the level of economic development in the central and western regions of China is 
low, and factors such as industrial environment and human capital also restrict the absorption capacity of technology to a certain extent. Therefore, the Chinese government should take measures to promote the balanced development of the regional economy.

Finally, China should encourage domestic technology companies to "go global". Since 2000, the industry covered by OFDI in China has gradually expanded, but the industrial level is still low. It is mainly reflected in the following two aspects: First, the investment is concentrated in industries with low technical content and low added value such as general processing and primary product manufacturing; second, it focuses on industries such as resource development and general service industries and is technologyintensive. Investment in industry and high-end services is small. China should encourage manufacturing companies such as automobiles, home appliances, textiles and clothing, electronic information, and machinery and equipment to go out and improve the technological level of the industry by participating in international market competition and division of labor.

\section{ACKNOWLEDGEMENT}

This research was supported by the project, which has received funding from The Chinese Ministry of education of Humanities and Social Science project（Grant No.17YJC790077）

The paper is the output of an international scientific project IGA no. 2/2018 - M „Problems and Suggestions - Comparison of Commercial Environment between China - Slovakia and Facilitation of Trade and Investment".

\section{REFERENCES}

Bevan, A., Estrin, S., \& Meyer, K. (2004). Foreign investment location and institutional development in transition economies. International business review, 13(1), 43-64.

Bitzer, J., \& Kerekes, M. (2008). Does foreign direct investment transfer technology across borders? New evidence. Economics Letters, 100(3), 355-358.

Buckley, P. J., \& Casson, M. C. (1981). VThe Optimal Timing of a Foreign Direct Investment. $V$ Economic Journal, $91(361), 75-87$.

Cheung, Y. L., Connelly, J. T., Jiang, P., \& Limpaphayom, P. (2011). Does corporate governance predict future performance? Evidence from Hong Kong. Financial Management, 40(1), 159-197. https://doi.org/10.2307/41237900

Chinese Outbound Investment in the European Union (2013). European Chamber of Commerce in China, 26-28.

Coe, D. T., \& Helpman, E. (1995). International r\&d spillovers. European economic review, 39(5), 859-887.

Deng, M. (2012). Institutional Distance, "Demonstration Effect" and Location Distribution of China's OFDI. International Trade Issues, (2), 123-135.

Dunning, J.H. (1977). Trade, location of economic activity and the MNE: a search for an eclectic approach, in B. Ohlin, P.O. Hesselborn and P.M. Wijkmon (eds.) The International Location of Economic Activity, London: Macmillan.

Fabus, M. (2015) Impact of foreign direct investment on unemployment development in selected regions of Slovak Republic. Economic Annals-XXI, 155(11-12), 63-66

Fabus, M. (2017) Current development of business environment in Slovakia and Czech Republic. Entrepreneurship and Sustainability Issues, 5(1), 127-137. https://doi.org/10.9770/jesi.2017.5.1(10)

Fabus, M. (2018). Business environment analysis based on the Global Competitiveness Index (GCI) and Doing Business (DB): case study Slovakia. Journal of Security and Sustainability Issues, 7(4), 831-839. https://doi.org/10.9770/jssi.2018.7.4(18)

Fosfuri, A., \& Motta, M. (1999) Multinationals without advantages. Scandinavian Journal of Economics, 101, 617-630.

Kogut, B., \& Chang, S. J. (1991). Technological Capabilities and Japanese direct investment in the United States. Review of Economics and Statistics, 73(3), 401-413. 
Lee, M., Yin, X., Lee, S., Weng, D. H., \& Peng, M. (2015) The impact of home country institutions on new venture export: examining new ventures in transition economies. International Entrepreneurship \& Management Journal, 11(4), 823-848.

Potterie, B. V. P. D. L., \& Lichtenberg, F. (2001). Does foreign direct investment transfer technology across borders?. Review of Economics and Statistics, 83(3), 490-497.

Morreale, J.C., Shostya, A., \& Villada, M. (2018). China's rising middle class: A case study of Shanghai college students. Journal of International Studies, 11(2), 9-22. doi:10.14254/2071-8330.2018/11-2/1

Nechtelberger, A., Renner, W., Nechtelberger, M., Supeková, S. C., Hadjimarkou, M., Offurum, C., ... \& Redfern, K. (2017). Adopting Basic Principles of the United Nations Academic Impact Initiative (UNAI): Can Cultural Differences Be Predicted from Value Orientations and Globalization?. Frontiers in psychology, 8, 1977.

Pokrivčák, J., Chovanová Supeková, S., Lančarič, D., Savov, R., Tóth, M., Vašina, R. (2019). Development of beer industry and craft beer expansion. Journal of Food and Nutrition Research, 58(1), 63-74.

Raišiene, A. G., Yatsenko, O., Nitsenko, V., Karasova, N., \& Vojtovicova, A. (2019). Global dominants of Chinese trade policy development: Opportunities and threats for cooperation with Ukraine. Journal of International Studies, 12(1), 193-207. doi:10.14254/2071-8330.2019/12-1/13

Serapio M. G., \& Dalton D. H. (1999). Globalization of industries R\&D: An Examination of Foreign Direct Investment in R\&D the United States. Research Policy, 28(2-3), 30-316.

Shuyan, L., \& Fabus, M. (2019). Study on the spatial distribution of China's Outward Foreign Direct Investment in $\mathrm{EU}$ and \& its influencing factors, Entrepreneurship and Sustainability Issues, 6(3), 1080-1096. http://doi.org/10.9770/jesi.2019.6.3(16)

Stopford, J. M. (2008). Multinational enterprises and the global economy. Journal of International Business Studies, 39(7), 1236-1238.

Vdovtsova, S. (2008). Motivation mechanisms of youth behavior on ukrainian labour market. Economics and Sociology, 1(1), 105-108.

Wang, Y. and Liu, S. (2008). An Empirical Study of the International Technology Spillover Channels. The Journal of Quantitative \& Technical Economics, 4, 153-161.

Wells. (1977). The Internationalization of Firms from Developing Countries. Multinationals from Small Countries, Cambridge, MA: MIT Press

Yuan, X., \& Zhang, Y. (2018). OFDI Reverse Technology Spillovers of Western China. Open Journal of Social Sciences, 6, 62-70. doi: 10.4236/jss.2018.62006.

Zhao, W., \& He, Y. (2006). Extroverted FDI and China's Technological Progress: Mechanism Analysis and Tentative Demonstration. Management World, 7, 53-60. 